\title{
EPIDEMIOLOGY OF FEMUR FRACTURES IN THE ELDERLY AND COST TO THE STATE OF PARANÁ, BRAZIL
}

\section{EPIDEMIOLOGIA DAS FRATURAS DE FÊMUR EM IDOSOS E SEU CUSTO PARA O ESTADO DO PARANÁ, BRASIL}

\author{
Camila Cristine Oliveira ${ }^{1}$, Victoria Zeghil Cochenski Borba ${ }^{2}$ \\ 1. Universidade Federal do Paraná, Curitiba, PR, Brazil. \\ 2. Universidade Federal do Paraná, Hospital de Clínicas, Department of Internal Medicine, Endocrinology and Metabology Division, Curitiba, PR, Brazil.
}

\section{ABSTRACT}

Objectives: To evaluate the incidence and economic impact of femur fractures in the state of Paraná, Brazil. Methods: This descriptive study included men and women $\geq 60$ years of age with hip fractures which were treated by the Public Health System in emergency care from January 2010 to December 2014. Data were collected from the DATASUS public health database using filters to select patients; results were presented descriptively and as proportions. The standardized incidence of femur fracture was calculated by sex and age for 10,000 inhabitants in Paraná state and in Brazil for the year 2012. Results: During the study period, 11,226 fractures were registered, $66.8 \%$ in women and $33.2 \%$ in men. There was a preponderance of fractures in Caucasians and in older age groups. Mortality during hospitalization was $5.9 \%$, higher in males, in patients aged $\geq 80$ years, and in Blacks and Asians. The total cost was $R \$ 29,393,442.78$ and the average cost per hospitalization was $R \$ 2,618.34$. The eastern region of the state had the highest rate of fractures, predominantly in the capital, Curitiba. The standardized incidence rate was higher in females and in the population of Paraná. Conclusion: Femur fractures have a high incidence rate in the elderly population of Paraná and a large economic impact. Level of Evidence II, Prognostic Studies Investigating the effect of a Patient Characterisctic on the Outcome of Disease.

Keywords: Incidence. Fractures, bone. Femur. Aged. Costs and cost analysis.

\section{RESUMO}

Objetivo: Avaliar a incidência e o impacto econômico das fraturas de fêmur no Estado do Paraná, Brasil. Métodos: Este estudo descritivo incluiu homens e mulheres $\geq 60$ anos de idade com fraturas de quadril, tratados no serviço de emergência do Sistema Único de Saúde, de janeiro de 2010 a dezembro de 2014. Os dados foram coletados na base de dados DATASUS, usando-se filtros para selecionar os pacientes; os resultados foram apresentados de forma descritiva e proporcional. A incidência padronizada de fratura femoral foi calculada por sexo e faixa etária em 10 mil habitantes do Estado do Paraná e no Brasil, referente ao ano de 2012. Resultados: Durante o período de estudo, foram registradas 11.226 fraturas, $66,8 \%$ em mulheres e $33,2 \%$ em homens. Houve predomínio de fraturas em brancos e mais idosos. A taxa de mortalidade durante a internação foi 5,9\%, maior nos homens, na faixa etária de 80 anos ou mais, negros e asiáticos. O custo total foi $R \$ 29.393 .442,78$ e o custo médio por internação foi $R \$ 2.618,34$. A taxa mais alta de fraturas ocorreu na região leste do estado, predominantemente na Capital, Curitiba. A taxa de incidência padronizada foi superior nas mulheres e na população paranaense. Conclusão: As fraturas de fêmur têm alta incidência em idosos no Estado do Paraná, com alto impacto econômico. Nível de Evidência II, Estudos Prognósticos - Investigação do Efeito de uma Característica de um Paciente sobre o Desfecho da Doença.

Descritores: Incidência. Fraturas ósseas. Fêmur. Idoso. Custos e análise de custo.

Citation: Oliveira CC, Borba VZC. Osteoporosis in brazilian patients awaiting knee arthroplasty. Acta Ortop Bras. [online]. 2017;25(4):155-8. Available from URL: http://www.scielo.br/aob.

\section{INTRODUCTION}

Population aging is a trend of emerging and developed countries, increasing chronic-degenerative diseases. It is estimated that the percentage of the Brazilian population aged 60 years or more will increase from $11.71 \%$ in 2015 to $33.71 \%$ in $2060 .{ }^{1}$ In this context, osteoporosis represents a public health problem, since it increases the risk of femur fracture in the elderly, a condition with high morbidity and mortality and high costs. Osteoporotic fractures are usually related to falls and have known risk factors such as advanced age, female gender, early menopause, sedentary lifestyle, among others. ${ }^{2}$ The incidence of fracture increases with age and maintains a higher proportion in females. ${ }^{3}$

All authors declare no potential conflict of interest related to this article.

Study conducted at Universidade Federal do Paraná, Curitiba, PR, Brazil.

Correspondence: Victoria Z C Borba. Serviço de Endocrinologia e Metabologia do Hospital de Clínicas da Universidade Federal do Paraná (SEMPR), Av. Agostinho Leão Junior, 285, Alto da Glória, Curitiba, PR, Brazil. 80030-110. vzcborba@gmail.com 
The fracture treatment is surgical in most cases and the longer the patient remains bedbound, the greater the chances of having complications such as infection, deep venous thrombosis, and pulmonary embolism. ${ }^{4,5}$

The mean mortality rates, estimated by a recent review, were $5.5 \%$ during hospitalization and ranged from $4.7 \%$ in the first month, $10.8 \%$ in the 6 th month to $24.9 \%$ in the second year. Advanced age, number of comorbidities, male gender, and presence of cognitive deficits were identified as the main factors related to higher mortality. ${ }^{6}$

In addition to high mortality, femoral fracture also presents a high morbidity rate and functional impairment, causing a psychosocial impact with the degree of post-fracture dependence, reaching $30 \%{ }^{7,8}$ Total expenditures on hospitalization for femoral fractures in the elderly in Brazil were around 40 million $\mathrm{R} \$$ per year in the threeyear period of 2006-2008, representing about $2 \%$ of all causes of hospitalization among the elderly. ${ }^{9}$

Driven by the absence of data on osteoporotic femoral fractures in the State of Paraná and the need to know the magnitude of the problem and its costs to the public health care system (SUS), the present study aims to assess the incidence and economic impact that this morbidity represented for the state in the period from January 2010 to December 2014.

\section{METHODS}

A descriptive study on femoral fractures was carried out in elderly people living in the state of Paraná from January 2010 to December 2014. Elderly is considered to be 60 years of age or older.

The study was approved by the Ethics Committee of the Hospital de Clínicas da Universidade Federal do Paraná, number 19749613.3.0000.0096. Data were collected from the Department of Information Technology of SUS (DATASUS; http://www.datasus.gov.br) on April 25, 2015, accessing the links in the following sequence: health information (TABNET) - epidemiological and general morbidity by place of residence as of 2008 - State of Paraná (on the map). The selection of the outcome of interest was performed based on the main diagnosis "Femur fracture" ICD-10: 72.0 to 72.9. The following filters were then selected: January 2010 to December 2014, ICD 10 morbidity list - femur fracture, emergency care character, age group of 60 years or more, sex, color / race, number of hospitalizations, mean length of stay (days), total and average hospitalization cost, number of deaths, mortality rate, chapter ICD-10 all categories (filter used to compare costs with other comorbidities). These filters correspond to the studied variables. Inclusion criteria were as follows: men and women of any ethnic group, age 60 years or older, with femoral fracture, urgent care admission, attendance by the SUS, from January 2010 to December 2014, and data present on the basis of DATASUS.

Exclusion criteria did not apply to the present study.

The data were presented in a descriptive and proportional way when pertinent. The incidence rates of femur fracture per 10,000 people, standardized by sex and age group in the state of Paraná and in Brazil for the year 2012, were calculated.

\section{RESULTS}

From January 2010 to December 2014, 11,226 elderly people $\geq 60$ years old, living in the state of Paraná, were hospitalized for a femoral fracture in SUS hospitals. There was a predominance of females with 7,497 cases $(66.8 \%)$, while 3,729 (33.2\%) cases were males. The data corresponding to ethnicity are shown in Table 1. Despite the absence of information in $27.5 \%$ of the cases, there was a predominance of fractures in Caucasians (64.6\%). The number of fractures increased progressively with aging. (Table 2)
Out of the 11,226 elderly patients hospitalized for a femoral fracture, 660 died, corresponding to a mortality rate of $5.9 \%$. Although the higher incidence of fractures occurred in females, the mortality rate was greater in males, 80 or more years old, black and Asian. There was no major difference throughout the years studied. (Table 3) The total cost of fractures in the period from 2010 to 2014 was $R \$ 29,393,442.78$, and the mean cost for hospitalization was $\mathrm{R} \$ 2618.34$, similar between sexes and higher in patients aged 80 years or over ( $R \$ 2831.73)$. The mean cost per hospitalization to treat a femoral fracture was higher than that calculated for neoplasms, infectious diseases, circulatory system diseases, among others, in the assessed period. (Table 4)

Table 1. Number of femoral fractures according to ethnicity.

\begin{tabular}{c|c|c}
\hline Ethnicity & Number of fractures & $\%$ \\
\hline Caucasian & 7253 & 64,61 \\
\hline Mutato & 683 & 6,08 \\
\hline Black & 145 & 1,29 \\
\hline Asiana & 55 & 0,49 \\
\hline Indigenous & 1 & 0,008 \\
\hline Not available & 3089 & 27,52 \\
\hline Total & 11226 & 100 \\
\hline Source: Datasus; (htpp://mww datasus govbr) April 25, 2015.
\end{tabular}

Table 2. Number of fractures according to age group.

\begin{tabular}{c|c|c}
\hline Age & Number of fracturess & $\%$ \\
\hline $60-69$ years & 2248 & 20,02 \\
\hline $70-79$ anos & 3920 & 34,92 \\
\hline$\geq 80$ years & 5058 & 45,06 \\
\hline Total $(\geq 60$ years $)$ & 11226 & 100
\end{tabular}

Source: Datasus; (http://www.datasus.gov.br) April 25, 2015.

Table 3. Deaths and mortality by sex, ethnicity and studied period.

\begin{tabular}{c|c|c|c|c}
\hline \multicolumn{2}{c|}{} & $\begin{array}{c}\text { Number of } \\
\text { fractures }\end{array}$ & $\begin{array}{c}\text { Number of } \\
\text { deaths }\end{array}$ & $\begin{array}{c}\text { Mortality } \\
\text { rate (\%) }\end{array}$ \\
\hline \multirow{4}{*}{ Gender } & Total & 11226 & 660 & 5,88 \\
\cline { 2 - 5 } & Female & 7497 & 433 & 5,78 \\
\hline \multirow{4}{*}{ Age } & Male & 3729 & 227 & 6,09 \\
\cline { 2 - 5 } & 60 a 69 anos & 2248 & 57 & 2,54 \\
\cline { 2 - 5 } & 70 a 79 anos & 3920 & 162 & 4,13 \\
\cline { 2 - 5 } & $\geq 80$ anos & 5058 & 441 & 8,72 \\
\hline \multirow{4}{*}{ Year } & 2010 & 1971 & 113 & 5,73 \\
\cline { 2 - 5 } & 2011 & 2114 & 123 & 5,82 \\
\cline { 2 - 5 } & 2012 & 2189 & 126 & 5,76 \\
\cline { 2 - 5 } & 2013 & 2401 & 147 & 6,12 \\
\cline { 2 - 5 } & 2014 & 2551 & 151 & 5,92 \\
\hline \multirow{5}{*}{ Ethnicity } & Caucasian & 7253 & 427 & 5,89 \\
\cline { 2 - 5 } & Mulato & 683 & 34 & 4,98 \\
\cline { 2 - 5 } & Black & 145 & 11 & 7,59 \\
\cline { 2 - 5 } & Asian & 55 & 4 & 7,27 \\
\cline { 2 - 5 } & Indigenous & 1 & 0 & 0 \\
\cline { 2 - 5 } & Not Available & 3089 & 184 & 5,96 \\
\hline
\end{tabular}

Source: Datasus; (http://www.datasus.gov.br) April 25, 2015. 
The average hospitalization period was 6.9 days. No difference was found between sexes, ethnic groups, or years studied. The group of 80 years or older had a longer average stay (7.2 days). Considering the great regions of the state, the eastern region had the highest number of cases (4,982); in Curitiba and the metropolitan area there were 2,969 hospitalizations, of which $70.1 \%$ occurred in the state capital, followed by the city of São José dos Pinhais with $7.9 \%$ of the total. In Curitiba, one hospital named Hospital do Trabalhador treated most of the cases (1019).

The incidence rate of femoral fracture per 10,000 inhabitants standardized by gender and age ( $\geq 60$ years) was higher in females compared to males in the state of Paraná (25.14 / 10 thousand, females and 13.12 / 10 thousand, males, respectively) and in the whole country (22.58 / 10 thousand and 13.52 / 10 thousand respectively). The fracture rate in the female population of Paraná (25.14 / 10 thousand) was higher than the national female rate (22.58 / 10 thousand). Considering both sexes, the total standardized rate of fractures in Paraná (19.80 / 10 thousand) exceeded the national rate (18.55 / 10 thousand). (Table 5)

When the population was divided by age (60-69, 70-79, $\geq 80$ years), there was a progressive increase in the incidence of fractures with increasing age in all groups (male, female, and total population, in Paraná and Brazil), with a predominance in females and in the population of Paraná. (Table 5)

Table 4. Average hospital cost accoring to International Classification Disease (ICD)-10 code.

\begin{tabular}{c|c}
\hline CID-10 Code & Average hospitalization cost \\
\hline Infectious diseases & $\mathrm{R} \$ 1.063,50$ \\
\hline Neoplasia (tumors) & $\mathrm{R} \$ 1.582,12$ \\
\hline Mental and behavioral disorders & $\mathrm{R} \$ 1.530,93$ \\
\hline Nervous System Disease & $\mathrm{R} \$ 1.310,22$ \\
\hline Circulatory Disease & $\mathrm{R} \$ 2.485,57$ \\
\hline Respiratory Disease & $\mathrm{R} \$ 897,43$ \\
\hline Femur Fracture & $\mathrm{R} \$ 2.618,34$
\end{tabular}

Source: Datasus; (http://www.Datasus.Gov.Br) april 25, 2015.

Table 5. Standardized incidence ratio of femoral fractures per 10,000 inhabitants by sex and age.

\begin{tabular}{c|c|c|c|c|c}
\hline \multicolumn{2}{c|}{ Rate } & $60-69$ years & $\mathbf{7 0 - 7 9}$ years & $\geq 80$ years & Total $\geq 60$ years \\
\hline \multirow{4}{*}{ Paraná } & Female & 6.68 & 26.31 & 85.27 & 25.14 \\
\cline { 2 - 6 } & Male & 5.5 & 15.5 & 42.78 & 13.12 \\
\cline { 2 - 6 } & Total & 6.13 & 21.58 & 68.88 & 19.8 \\
\hline \multirow{3}{*}{ Brazil } & Female & 6.65 & 23.88 & 73.82 & 22.58 \\
\cline { 2 - 6 } & Male & 7.13 & 14.63 & 40.57 & 13.52 \\
\cline { 2 - 6 } & Total & 6.87 & 19.84 & 61.01 & 18.55 \\
\hline
\end{tabular}

\section{DISCUSSION}

The present study is pioneer in compiling recent data that allow the evaluation of the behavior of femoral fractures in the elderly in the State of Paraná

The study presented results consistent with the literature regarding the higher incidence of fractures in females and in the higher age groups. 3,10,11 The male / female ratio observed of 1: 2.01 was similar to that in Sobral, Ceara (1:1.7), and lower than that in Recife, Pernambuco (1:3.02). Women are more likely to develop osteoporosis and, consequently, fractures as observed in the BRAZOS study. ${ }^{2}$ Caucasian was the prevalent ethnicity, which was not demonstrated in the national BRAZOS study. ${ }^{2}$ We should consider that the population of Paraná is mostly Caucasian, which can cause a bias in the results, the same being observed in Pelotas, Rio Grande do Sul. ${ }^{12}$ Femoral fracture is a condition of high mortality during hospitalization and months and years following the fracture. In this study, the mortality rate was $5.88 \%$ during the hospital stay, similar to that observed in a review of 25 studies, ${ }^{6}$ which showed an average rate of mortality in the post-fracture period of $11.9 \%, 19.2 \%$, and $24.9 \%$ at 3 months, one year, and two years, respectively.

Although the number of fractures was higher in females, mortality rates were greater in males (6.1\%), blacks (6.6\%), Asians (7.3\%), and people 80 years of age or older(8.7\%), consistent with national and international literature..$^{13-17}$

The literature also shows a high morbidity related to femoral fractures, with some degree of physical limitation around 4 months after a fracture..$^{18}$ In a prospective study of 68 patients, only $32.56 \%$ reacquired the walking capacity and $27.9 \%$ of the previously independent patients needed special care. ${ }^{7}$

As a condition of high prevalence among the elderly, whose treatment is essentially surgery ${ }^{5}$ and a long hospital stay, femoral fracture entails high costs. In the triennium 2006-2008, femur fracture accounted for $2 \%$ of the expenditures of all hospitalizations in the elderly over 60 years in Brazil, and cost approximately $\mathrm{R} \$ 120$ million. ${ }^{9}$ In the 5 years studied (2010 to 2014), the hospitalization for femoral fracture in the elderly cost the State of Paraná around $\mathrm{R} \$ 29$ million, with an average cost for hospitalization of $\mathrm{R} \$ 2,618.34$. This cost for hospitalization was higher than that calculated for neoplasms, infectious diseases, including the diseases of the circulatory system, among others.

The mean hospital stay found in this study (6.9 days) is consistent with the national literature. Studies carried out in the cities of Sobral ${ }^{19}$ and Brasiliaa ${ }^{20}$ showed an average stay of 7.2 and 7.1 days, respectively. An interesting issue pointed out by Bortolon et al. ${ }^{9}$ was that the early discharge from the hospital was associated with the lack of guidance regarding the diagnosis of osteoporosis and the need for physical therapy. The BRAZOS study showed that $70 \%$ of women and $85 \%$ of men with previous history of low-impact fracture were unaware of the diagnosis of osteoporosis. ${ }^{2}$

The most populous eastern region concentrated the majority of the hospitalizations, with the capital, Curitiba, having most of the cases, probably due to better structure and the presence of the Workers' Hospital, which is a reference center for trauma.

The total standardized incidence rate ( $\geq 60$ years) was higher in females and increased progressively with increasing age similar to that in other epidemiological studies. ${ }^{3,11}$ The female and total rates in Paraná were superior to the national one, in agreement with the findings of Silveira et al., ${ }^{11}$ who believed that the incidence of femur fracture in the elderly is higher in the southern region due to colder temperatures and lower incidence of sunlight, which favors osteoporosis. Taking this into account, we expected that the rate of fractures in Paraná $\left(24^{\circ} 00^{\prime} \mathrm{S}, 51^{\circ} 00 \mathrm{~W}\right.$ ) would be similar to that calculated for the same age group ( $\geq 60$ years) in the city of Marília, São Paulo (50.03 / 10 thousand female inhabitants and 18.73 / 10 thousand male inhabitants) and to exceed Fortaleza's rates (27.5 / 10 thousand female inhabitants and 13/10 thousand male inhabitants); however, we obtained a rate similar to that of Fortaleza $\left(03^{\circ} 43^{\prime} \mathrm{S}, 38^{\circ} 32^{\prime} \mathrm{W}\right)$ and well below that of Marília (220 $\left.12^{\prime} \mathrm{S}, 49^{\circ} 56^{\prime} \mathrm{W}\right) .^{10,11}$

The fact that we did not capture patients covered by private care insurance could have interfered in the rate of our study. Also, this study was realized many years after Marília's study (1995), when the ratio of osteoporosis treatment was lower, which may have impacted the fracture rate.

The main limitation of this study was the impossibility of confirming the osteoporotic character of the fractures, since in the DATASUS database there is only a general diagnosis of "femur fracture." However, considering that the higher incidence of fractures and osteoporosis occurs in the more advanced age, we inferred that osteoporosis was the main cause of fractures in the population studied. 


\section{CONCLUSION}

From these results, we can conclude that femoral fractures in the State of Paraná represent a public health problem due to their high incidence and economic impact. The incidence is higher in females, Caucasian, and older age groups. The male sex, blacks,
Asians, and oldest groups presented the highest mortality rates. Considering osteoporosis as the primary cause of fractures in the elderly, the creation of public policies aimed to prevent and treat this disease should be encouraged in the State of Paraná.

AUTHORS' CONTRIBUTIONS: Each author made significant individual contributions to this manuscript. CCO (0000-0002-4863-9394)* and VZCB (00000003-0555-0880)* drafted the manuscript and were responsible for collecting and analyzing the data, bibliographical research, review of the manuscript, and the intellectual concept of the study. ${ }^{*}$ ORCID (Open Researcher and Contributor ID).

\section{REFERENCES}

1. IBGE. Instituto Brasileiro de Geografia e Estatística. Projeção da população e indicadores sociais. Gerência de estudos e análises da dinâmica demográfica. Projeção da população do Brasil por sexo e idade para o período de 2000-2060. [acesso em 2015 abr 25]. Disponível em: http://www.ibge.gov.br/home/estistica/ populacao/projecao_da_populacao/2013/default.shtm.

2. Pinheiro MM, Ciconelli RM, Jacques NO, Genaro PS, Martini LA, Ferraz MB. O impacto da osteoporose no Brasil: dados regionais das fraturas em homens e mulheres adultos - The Brazilian Osteoporosis Study (BRAZOS). Rev Bras Reumatol. 2010;50(2):113-27.

3. Ramalho AC, Lazaretti-Castro M, Hauache O, Vieira JG, Takata E, Cafalli F, et al. Osteoporotic fractures of proximal femur: clinical and epidemiologicalfeatures in a population of the city of São Paulo. Sao Paulo Med J. 2001;119(2):48-53.

4. Borges AED, Araújo KMB, Stolt LRO, Ferreira JJD. Caracterização das fraturas do fêmur em pacientes de um Hospital de Emergência e Trauma em João Pessoa- PB no período de 2008/2009. Rev Bras Cienc Saúde. 2012;16(4):507-16.

5. Pires RES, Fernandes HJA, Belloti JC, Balbachevsky D, Faloppa F, Reis FB. Como são tratadas as fraturas diafisárias fechadas do fêmur no Brasil? Estudo Transversal. Acta Ortop Bras. 2006;14(3):165-9.

6. Sakaki MH, Oliveira AR, Coelho FF, Leme LEG, Suzuki I, Amatuzzi MM. Estudo da mortalidade na fratura do fêmur proximal em idosos. Acta Ortop Bras. 2004;12(4):242-9.

7. Rocha MA, Azer HW, Nascimento VG. Evolução funcional nas fraturas da extremidade proximal do fêmur. Acta Ortop Bras. 2008;17(1):17-21.

8. Fortes EM, Raffaelli MP, Bracco OL, Takata ETT, Reis FB, Santili C, et al. Elevada morbimortalidade e reduzida taxa de diagnóstico de osteoporose em idosos com fratura de fêmur proximal na cidade de São Paulo. Arq Bras Endocrinol Metab. 2008;52(7):1106-14.

9. Bortolon PC, Andrade CLT, Andrade CAF. O perfil das internações do SUS para fratura osteoporótica de fêmur em idosos no Brasil: uma descrição do triênio 2006-2008. Cad Saúde Pública. 2011;27(4):733-42.
10. Komatsu RS, Simões MFJ, Ramos LR, Szejnfeld VL. Incidência de fraturas do fêmur proximal em Marília, São Paulo, Brasil, 1994 e 1995. Rev Bras Reumatol. 1999;39(6):325-31.

11. Silveira VAL, Medeiros MMC, Coelho-Filho JM, Mota RS, Noleto JCS, Costa FS, et al. Incidência de fratura do quadril em área urbana do Nordeste brasileiro. Cad Saúde Pública. 2005;21(3):907-12.

12. Siqueira FV, Facchini LA, Hallal PC. The burden of fractures in Brazil: a population-based study. Bone. 2005;37(2):261-6.

13. Gawryszewski VP. A importância das quedas no mesmo nível entre idosos no Estado de São Paulo. Rev Assoc Med Bras. 2010;56(2):162-7.

14. Mesquita GV, Lima MAL, Santos AMR, Alves ELM, Brito JNP, Martins MCC. Morbimortalidade em idosos por fratura proximal do fêmur. Texto contexto Enferm, Florianópolis. 2009;18(1):67-73.

15. Melton III LJ, Marquez MA, Achenbach SJ, Tefferi A, O'Connor MK, O'Fallon WM, et al. Variations in bone density among persons of African heritage. Osteoporos Int. 2002;13(7):551-9.

16. Dzupa V, Bartonícek J, Skála-Rosenbaum J, Príkazský V. Mortality in patients with proximal femoral fractures during the first year after the injury. Acta Chir Orthop Traumatol Cech. 2002;69(1):39-44

17. Cree M, Soskolne CL, Belseck E, Hornig J, McElhaney JE, Brant R, et al. Mortality and institutionalization following hip fracture. J Am Geriatr Soc. 2000; 48(3):283-8

18. Mendonça TM, Silva CH, Canto RS, Morales NM, Pinto RM, Morales RR. Evaluation of the health-related quality of life in elderly patients according to the typeof hip fracture: femoral neck or trochanteric. Clinics (Sao Paulo). 2008;63(5):607-12

19. Rocha FAC, Ribeiro AR. Baixa incidência de fraturas do quadril associadas à osteoporose, em Sobral-CE. Rev Bras Reumatol. 2004;4(4):255-8.

20. Arndt ABM, Telles JL, kowalski SC. O custo direto da fratura de fêmur por quedas em pessoas idosas: análise no setor privado de saúde na cidade de Brasília, 2009. Rev Bras Geriatr Gerontol. 2011;14(2):221-31. 